\title{
PEMANFAATAN DAN MAKNA AIR DALAM VEDA
}

\author{
Ni Luh Gede Sudaryati \\ Program Studi Biologi, FMIPA, Universitas Hindu Indonesia \\ ,I Made Dwi Mertha Adnyana \\ Program Studi Biologi, FMIPA, Universitas Hindu Indonesia
}

\begin{abstract}
ABSTRAK
Air merupakan kebutuhan yang sangat penting dalam suatu makhluk hidup mengingat, air menjadikan segala jenis makhluk hidup dapat tumbuh dan berkembang dengan baik. Penelitian ini bertujuan untuk memberikan gambaran mengenai pemanfaatan dan makna air dalam Veda. Penelitian ini menggunakan desain penelitian deskriptif kualitatif. Penelitian ini dilakukan selama 1 bulan pada bulan Agustus 2018. Berdasarkan hasil kajian menunjukkan bahwa pemanfaatan air di masyarakat bersumber dari ajaran Veda, yang memiliki makna di masing-masing pemanfaatan tersebut. Adapun pemanfaatan dan makna air dalam Veda sebagai berikut: Air sebagai makna penyembuhan, makna kesuburan, makna penyucian, makna keabadian, makna siklus, dan air sebagai makna pelestarian.
\end{abstract}

Kata Kunci: Air, Makna, Veda, Pemanfaatan.

\section{PENDAHULUAN}

Air merupakan kebutuhan yang sangat penting dalam suatu makhluk hidup mengingat, air menjadikan segala jenis makhluk hidup dapat tumbuh dan berkembang dengan baik. Kita ketahui bersama bahwa semua kehidupan ini berawal dari air, membutuhkan air, dan kembali lagi menjadi air. Air banyak dimanfaatkan oleh manusia dari untuk kebutuhan diri sendiri, pertanian, perkebunan, peternakan, perindustrian, energi, dan kebutuhan lainnya. Air juga tidak hanya dimanfaatkan oleh manusia. Hewan membutuhkan air. Tumbuhan membutuhkan air untuk berfotosintesis, dan bahkan makhluk kecil mikroorganisme pun membutuhkan air. Sehingga tidak salah jika kita menyampaikan bahwa air adalah kehidupan (Karta, I W, 2013).

Hal ini pun tidak terlepas dari keberadaan air sebagai penyusun terbanyak di bumi sebagai unsur Buana Agung, dan tubuh manusia sebagai unsur buana alit. Secara biologi, kandungan air dalam tubuh manusia sekitar 2 / 3 atau sekitar $60 \%-70 \%$ dari berat tubuh. Tetapi, kandungan air dalam lemak hanya sekitar10\%, sehingga untuk yang orang yang mengalami problem kegemukan atau obesitas, persentase kandungan air dalam tubuhnya bisa kurang dari angka 60. Jumlah air dalam tubuh manusia juga tergantung usia, jumlah air dalam tubuh bayi (80\%), orang dewasa (70\%), dan lanjut usia (50\%). Jumlah air yang 
banyak tersebut tersebar dalam organorgan tubuh manusia, seperti paru-paru $(90 \%)$, darah (82\%), kulit (80\%), otot $(75 \%)$, otak $(70 \%)$, dan tulang $(22 \%)$. Tubuh manusia membutuhkan antara satu sampai tujuh liter air setiap hari untuk menghindari dehidrasi; jumlah pastinya bergantung pada tingkat aktivitas, suhu, kelembaban, dan beberapa faktor lainnya. Dan air dalam tubuh dikeluarkan minimal $500 \mathrm{~mL}$ sehari, dan bisa juga sampai 2,5 liter (Karta, I W, 2013).

Air memiliki manfaat dan makna tersendiri, sehingga seluruh masyarakat dan seluruh makhluk hidup di bumi menggunakan air. Umat Hindu di Bali memandang dan menggangap air merupakan karunia tuhan tertinggi. Mengingat tanpa adanya air suatu kehidupan tidak akan ada di muka bumi ini. Hal inilah yang membawa pandangan masyarakat Hindu untuk selalu menjaga kesucian, kebersihan dan pengeloloaan yang baik mengenai air. Banyak hal yang tertuang dalam kitab suci Veda yang dimiliki oleh umat Hindu mengenai air. Salah satunya konsep dari sad kertih (atma, samudra, wana, danu, jagat, dan jana kertih). Sehingga perlu dilakukan penelitian mengenai pemanfaatan dan makna air dalam Veda. Penelitian ini bertujuan untuk memberikan gambaran mengenai manfaat dan makna air yang tertuang di dalam Veda.

\section{METODE}

Penelitian ini menggunakan desain penelitian deskriptif kualitatif. Dengan mengkaji hasil yang telah diperoleh melalui study literature, baik jurnal, buku, hasil penelitian, dan majalah yang berkaitan dengan judul penelitian (Ratna, 2006). Penelitian ini dilakukan pada selama 1 bulan pada bulan
Oktober 2018. Hasil penelitian yang telah diperoleh, dianalisis dan ditungkan dalam bentuk narasi.

\section{PEMBAHASAN}

Berdasarkan kajian yang telah dilakukan menunjukkan bahwa, pemanfaatan dan makna air dalam Veda sangat luas. Adapun pemanfaatan dan makna air dalam Veda sebagai berikut:

\section{Air Sebagai Makna Penyembuhan}

Pemanfaatan air sebagai makna penyembuhan oleh masyarakat, khususnya umat Hindu sudah banyak digunakan. Baik dalam bentuk Tirtha atau air suci yang sudah diberikan mantra didalamnya untuk keperluan pengobatan. Air dalam konsep Veda dipuja dan diberikan penghormatan yang tinggi. Air sangat disucikan sebagai pemberi kehidupan. Dalam Veda banyak disebutkan manfaat air bagi kehidupan di dunia, salah satunya digunakan sebagai media pengobatan. Veda merekomendasikan bahwa air merupakan sarana yang paling efektif digunakan baik menjaga kesehatan, merawat dan menyembuhkan suatu penyakit. Beberapa hal yang mendasari penggunaan air yang disebutkan di dalam Veda sebagai berikut: "Kami mohon pada penguasa air agar menyembuhkan penyakit kami" (Rg.Veda X.9.5), "Sang Hyang Rudra adalah (pakar) perawatan dengan air (Hidrotherapy), kami memohon kepada-Nya untuk kesejahteraan dan kebahagiaan" (Rg.Veda I.43.4), "Air mengandung nectar (Minuman para dewa) dan memiliki khasiat sebagai pengobatan" (Rg.Veda I.23.19), "Air menyembuhkan berbagai bentuk penyakit" (Rg.Veda I.23.20), "Air adalah obat, ia mengusir penyakit, ia ,menyembuhkan semua jenis penyakit"

\section{VIDYA WERTTA}

Vol. 1 Nomor 2, Oktober 2018 
(Rg.Veda X.137.6), "Semua menyatakan bahwa air merupakan yang paling baik" (Atharva Veda VIII.7.3), "Semua dewata yang berjumlah 33 terdapat di dalam air dan melindungi umat manusia" (Atharva Veda XIX. 27.10), "Mandilah engkau dan celupkan bagian tubuh yang dipengaruhi oleh penyakit di dalam air" (Atharva Veda VI.57.2), "Kami mengumpulkan air hujan dan berhasil mencampurnya dengan nminuman segara soma. Semoga ia memberikan kemulian kepada kami” (Atharva Veda VIII.89.1), "semua dewa bertumpuk sedikit demi sedikit didalam air itu dan air mengambil benih alam semesta yang pertama di dalamnya" (Rg.Veda X.82.6), "Air yang mengalir dibawah cahaya matahari, merupakan air yang bersih atau bebas kuman" (Atharva Veda I.4.2).

Itulah keajaiban air yang tertuang di dalam Veda yang sangat berperan penting dalam kesehatan makhluk ciptaannya. Ditinjau dari dalam Veda disebutkan Siklus Hidrologi (Siklus Air), yang berawal dari penguapan air dilautan, kemudian naik keatas menjadi awan dan didorong oleh angin dan menghasilkan hujan baik di lautan, daratan, dan pegunungan yang menghidupi seluruh makhluk hidup di bumi. Sesuai yang tertuang dalam Veda disebutkan bahwa "Air yang mengalir menuju samudra, dan naik keatas menuju angkasa serta memelihara obat - obatan dimurnikan oleh sinar-sinar itu" (Yajur Veda I.12).

Banyak ahli merekomendasikan agar setiap hari manusia meminum air putih sebanyak 8-9 gelas atau setara dengan 2,5 liter yang bertujuan untuk menjaga keseimbangan cairan di dalam tubuh. Itulah dasar hendaknya setiap manusia menghargai air dan bersikap positif terhadap air. Di Bali, penggunaan air sebagai media pengobatan sangat popular yang dikenal dengan Usada we (Pengobatan yang menggunakan sarana air), yang diambil dari tempat suci, diupacarai, diberikan mantra, sehingga akan berdampak positif dan memiliki kemampuan untuk mengobati berbagai penyakit. Hal ini pun tidak terlepas dari keberadaan air sebagai penyusun terbanyak di bumi sebagai unsur Bhuana Agung, dan tubuh manusia sebagai unsur Bhuana Alit. Secara biologi, kandungan air dalam tubuh manusia sekitar 2/3 atau sekitar $60 \%-$ $70 \%$ dari berat tubuh. Tetapi, kandungan air dalam lemak hanya sekitar $10 \%$, sehingga untuk yang orang yang mengalami masalah berat badan, persentase kandungan air dalam tubuhnya bisa kurang dari angka $60 \%$. Jumlah air dalam tubuh manusia juga tergantung usia, jumlah air dalam tubuh bayi $(80 \%)$, orang dewasa $(70 \%)$, dan lanjut usia $(50 \%)$. Jumlah air yang banyak tersebut tersebar dalam organorgan tubuh manusia, seperti paru-paru $(90 \%)$, darah (82\%), kulit (80\%), otot (75\%), otak (70\%), dan tulang (22\%). Tubuh manusia membutuhkan antara 17 L air setiap hari untuk menghindari dehidrasi. Jumlah pastinya bergantung pada tingkat aktivitas, suhu, kelembaban, dan beberapa faktor lainnya serta air dalam tubuh dikeluarkan minimal $500 \mathrm{~mL}$ sehari, dan bisa juga sampai 2,5 liter.

Berdasarkan penelitian yang telah dilakukan oleh Adnyana, D.M (2018) mengenai pemanfaatan air sebagai media Hidrotherapy rendam kaki pada penderita hipertensi di Banjar Sri Mandala, Kelurahan Dauhwaru, Kabupaten Jembrana menunjukkan bahwa dari 15 orang yang menderita hipertensi yang digunakan sebagai

\section{VIDYA WERTTA}

Vol. 1 Nomor 2, Oktober 2018 
sampel penelitian, diberikan perlakuan Hidrotherapy rendam kaki dengan air hangat bersuhu $40^{\circ} \mathrm{C}$ dengan waktu 30 menit mampu menurunkan dan menstabilkan tekanan darah pasien sebesar tekanan darah sitolik 20-30 $\mathrm{mmHg}$ dan tekanan darah diastolik 0-10 $\mathrm{mmHg}$. Sehingga, dapat disimpulkan bahwa air mampu menstabilkan tekanan darah pasien dan sebagai pengobatan alternatif bagai penderita hipertensi. Penelitian ini sealan dengan konsep Veda yakni "Sang Hyang Rudra adalah (pakar) perawatan dengan air (Hidrotherapy), kami memohon kepada-Nya untuk kesejahteraan dan kebahagiaan"(Rg.Veda I.43.4).

\section{Air Sebagai Makna Kesuburan}

Masyarakat Bali sangat menghormati keberadaan air, karena dipercaya sebagai wujud Dewa Wisnu, salah satu manifestasi Tuhan Yang Maha Esa yang dipercaya sebagai pemelihara kehidupan dunia. Sakti Dewa Wisnu adalah Dewi Sri, dalam kehidupan sehari-hari dianalogikan dengan padi, sehingga padi tidak dapat dipisahkan dengan air. Itulah sebabnya para petani di Bali tergabung dalam subak (organisasi petani padi) sangat menghormati keberadaan air. Penghormatan terhadap air diwujudkan dengan berbagai upacara, di antaranya mendak toya. Mendak toya adalah upacara permohonan kepada Tuhan Yang Maha Esa agar air yang digunakan untuk mengairi sawah diberkahi, diselenggarakan menurut dewasa ayu (Rema, N.2013).

Salah satu daerah yang menyelenggarakan upacara mendak toya, yakni Kecamatan Penebel dengan membangun sebuah bendungan disebut temuku aya hulu yang dilengkapi dengan sebuah pura yang disebut pura empelan, dimanfaatkan sebagai tempat pelaksanaan upacara mendak toya. Upacara mendak toya dilaksanakan melalui suatu keputusan rapat subak, menjelang musim tanam. Rapat itu akan menetapkan hari baik mulai pengolahan tanah, penanaman, atau kadang-kadang menentukan jenis tanaman yang akan ditanam, dan pelaksanakan gotong royong memperbaiki dan membersihkan jaringan irigasi. Dengan demikian pura ini pun akan selalu diayomi secara rutin dan berkesinambungan oleh subak yang bersangkutan, menjelang dan pada saat pelaksanaan upacara (Windia, 2006: 1655 dalam Rema, N. 2013). Selain itu, di setiap pura yang ada di kawasan Penebel, Kabupaten Tabanan di dalam halaman utama dibangun sebuah palinggih sebagai pengayatan ke Danau Tamblingan. Hal ini mengingatkan akan fungsi Danau Tamblingan sebagai hulu dari setiap mata air yang muncul di daerah ini sebagai sumber kesuburan (Utami, 2013: 5-46). Bedasarkan hal inilah masyarakat yang menganut pekerjaan sebagai petani mengyebutkan bahwa air merupakan sumber kehidupan yang memberikan makna kesuburan dari setiap makhluk hidup di bumi.

\section{Air Sebagai Makna Penyucian}

Mata air adalah tempat yang diyakini suci oleh umat Hindu. Umat Hindu sangat pantang untuk berbuat yang bertentangan dengan ajaran agama di kawasan suci utamanya di lokasi mata air yang diyakini suci. Oleh karena itu setiap hulu mata air di Bali, umunya dibangun tempat untuk melakukan pemujaan, karena air dari mata air tersebut akan menjadi tirta yang sangat diperlukan dalam upacara panca yadnya. Menurut kitab Manasara Silpasastra memuat aturan secara rinci pembangunan kuil di India, yang pada pokoknya menjelaskan bahwa sebelum

\section{VIDYA WERTTA}

Vol. 1 Nomor 2, Oktober 2018 
bangunan kuil didirikan, arsitek pendeta (sthapaka) dan arsitek perencana (sthapati) harus lebih dahulu menilai kondisi dan kemampuan lahan yang akan dijadikan tempat berdirinya bangunan suci (Acharya, 1933: 13-15).

Kitab tersebut juga menguraikan syarat letak kuil sebagai pertanda kesucian, yakni berdekatan dengan sumber air, karena air mempunyai potensi untuk membersihkan, menyucikan, menyuburkan, sebagai pusat sasaran pemujaan. Potensi lahan dan air, merupakan hal primer, sedangkan candinya menduduki tempat nomor dua (Kramrisch, 1946: 5). Dengan keterangan tersebut dapat dinyatakan bahwa pertimbangan potensi lahan dan air, memainkan peranan penting dalam proses pemilihan lokasi sebagai tempat berdirinya bangunan keagamaan (Rema, N. 2013).

Salah satu hal penting yakni sumber air sebagai sarana paling suci dan harus didahulukan pembangunannya. Pembangunan kuil, agar diusahakan berdekatan dengan sumber air, karena air memiliki peranan yang sangat penting dalam kehidupan manusia. Karena pentingnya air (tirta) di kalangan penganut Hindu di India, sehingga air selalu disertakan pada setiap upacara. Suatu tempat suci apabila tidak ada tempat air atau kolam, maka dewa-dewa tidak akan berkenan hadir (Kramrisch, 1946: 3-5). Air sebagai lambang kesucian juga terdapat dalam Kitab Adiparwa, menyebutkan air atau tirtha yang berfungsi sebagai pembersih segala mala (kotoran) disebut samanta pancaka tirtha. Air dapat menghilangkan segala mala bagi para raja yang meninggal dalam peperangan, dan mandi pada air itu, mala -nya akan hilang dan dapat masuk surga (Tim, 2013: 233-235).
Menyinggung kembali tentang pancaka itrta. Terdapat tirta suci lima kolam itu disebut Pancaka Tirta. Setiap yang meninggal di tempat tirta tersebut, pastilah akan mendapatkan surga, demikian pula orang yang berbudi luhur mandi di sana, pastilah akan hilang segala kekotorannya, berhasil kembali ke surga. Demikian sabda leluhurnya, dibenarkan oleh para dewata. Semenjak itu hingga kini disebut sebagai Samanta Pancaka Tirta (Panitia Penyusun, 1997: 7). Jadi Pancaka Tirta merupakan konsep mendalam dipergunakan, dipelihara dengan baik salah satunya di mata air yang berada di Pura Tirta Empul, sebagai simbol kesucian, memberikan ruwatan menuju kesejatian. Tradisi menggunakan tirtha berasal dari petirtaan itu hingga sekarang masih berlaku. Hampir setiap hari orang-orang melakukan penglukatan (pembersihan diri) pada kolam suci tersebut (Bagus, 2008: 6768). Selain itu di Bali juga ada kepercayaan bahwa pertemuan dua buah sungai atau lebih disebut penyampuhan, memiliki nilai penting untuk ruwatan dan penyucian diri (prayascitta, malukat, atau mabayuh), dan tempat yang disenangi oleh para dewa dan rohroh suci untuk bercengkrama (Titib, 2009: 84).

\section{Air Sebagai Makna Keabadian}

Kisah mengenai amerta (air keabadian) termuat dalam cerita Samudramantana dalam kitab Adiparwa (Zoetmulder, 1994: 75-85). Penggunaan gunung sebagai pengaduk lautan untuk mendapatkan amerta ini berkaitan dengan kepercayaan bahwa gunung adalah pusat alam semesta. Di puncak gunung terletak kota para dewa yang dikelilingi oleh tempat tinggal para dewa penjaga mata angin (astadikpala atau astalokapala). Dalam ajaran agama

\section{VIDYA WERTTA}

Vol. 1 Nomor 2, Oktober 2018 
Hindu, sebagai pusat alam semesta adalah gunung Mahameru, yang dikelilingi oleh surya, bintang, bulan, dan dikelilingi oleh tujuh barisan pegunungan, yang satu dengan yang lain dipisahkan oleh sebuah samudra. Di lereng gunung Mahameru terdapat surga terendah, tempat tinggal para dewa penjaga keempat mata angin (catur lokapala). Di puncak gunung Mahameru terletak 33 buah surga milik masing-masing dewa dan kota Sudarsana yang merupakan kediaman Dewa Indra sebagai raja para dewata (Ardika, 2003: 95-96).

Gunung sebagai tempat tinggal para dewa merupakan tempat suci, terletak di arah kaja, sedangkan lautan sebagai simbol alam bawah, tempat kotor dan menakutkan terletak di arah kelod. Namun demikian laut dan gunung merupakan satu kesatuan yang tidak dapat dipisahkan dalam sistem kepercayaan masyarakat Bali, yang dikenal dengan konsep nyegaragunung. Konsep ini disebut sebagai konsep mandala yang bermakna lingkaran diagram yang memiliki kekuatan magis (Ardika, 2003: 94-97). Cирu amerta yang diambil oleh Dewa Indra dikembalikan ke kahyangan (di surga) di puncak gunung. Berarti telah terjadi siklus satu lingkaran, yaitu air amerta yang diwadahi cupu manik kembali ke gunung kemudian akan mengalir kembali berupa mata air dan kembali ke laut. Sebagian mengendap pada hewan, tumbuhan, manusia dan lain-lain, juga lambat laun akan kembali ke laut pula. Pada rumah, pintu gerbang sebagai replika gunung dalam kaitannya dengan microcosmos juga dipahatkan сири amerta sebagai simbol bahwa badan raganya, bangunannya, mendapatkan rahmat dari Tuhan agar dapat merasakan kebahagiaan, kemerdekaan atau kebebasan, keabadian-keluasan pemikiran.

\section{Air sebagai Makna Siklus}

Air yang mengalir ke laut berupa sungai disimbolkan dengan naga, yakni naga Basuki simbol air murni dari pegunungan, dan Naga Taksaka sebagai simbol awan. Naga acapkali digambarkan sebagai binatang mitologi yang bertempat hidup atau menjaga berbagai area perairan di bumi, semacam mata air, sungai, danau, atau lautan. Dalam pandangan dunia timur, juga dikorelasikan dengan segala sesuatu yang berhubungan dengan elemen air lainnya, seperti awan, hujan, bahkan pelangi. Para naga dalam berbagai mitologi bangsa timur juga dipandang sebagai binatang dari alam dewata yang bertugas mengatur curah hujan dan siklus peredaran air di dunia. Dalam konsepsi budaya tradisional Bali, dikenal adanya dua ekor naga yang sering dikorelasikan dengan keberadaan unsur air bumi. Kedua sosok naga itu adalah Naga Basuki yang dikonotasikan sebagai simbol aliran air, dan sosok Naga Taksaka yang dimaknai sebagai simbol awan atau udara di langit. Bagian ekor Naga Basuki dalam mitologi Manik Angkeran, digambarkan sebagai permata yang indah. Ekor Naga Basuki digambarkan berada di puncak gunung, sedangkan kepalanya di laut. Jadi jika ditafsirkan bahwa Basuki sebagai simbol air yang murni berasal dari pegunungan (ekor permata), dan bermuara di laut yang telah banyak tercemar limbah (kepala dan gigi taring yang beracun) (Paramadhyaksa, 2011: 270).

Di Bali ada kepercayaan bahwa saluran air baik itu di sungai, maupun di rumah tangga harus tetap dipelihara kelancarannya, jangan sampai tersumbat

\section{VIDYA WERTTA}

Vol. 1 Nomor 2, Oktober 2018 
karena akan dapat menimbulkan bencana. Jika di sungai akan menimbulkan banjir, jika dikeluarga akan menimbulkan dampak yang tidak baik, seperti bengka (sakit perut), karena metabolisme tidak lancar. Hal ini terjadi karena adanya hubungan secara langsung antara microcosmos (badan manusia) dengan macrocosmos (lingkungan). Itu sebabnya orang Bali selalu membuat saluran air untuk memperlancar jalannya air sesuai dengan tempatnya, dan tidak mengalir pada tempat yang salah sebab akan berdampak juga pada yang lain. Sehingga pada bagian dasar tembok pagar pekarangan, pura dan bangunan lainnya selalu dibuatkan tempat keluarnya air (song sombah), dan dihaturkan sesajen (Paramadhyaksa, 2011)

Perjalanan air dari pegunungan hingga sampai di laut dipandang sebagai sebuah siklus sangkan-paran, di mana air dalam pelajaran Ilmu Pengetahuan Alam memandang laut sebagai sumber air. Air laut yang mendapatkan pemanasan sinar matahari akan menguap menjadi awan, awan yang sudah jenuh akan menetes berupa hujan, air hujan tiba di bumi diserap oleh akar tanaman, karena banyak lalu memunculkan mata air dan sejenisnya, kemudian mengalir dan meresap menghidupi segala alam, kemudian kembali ke laut. Proses lingkaran ini terjadi secara terus menerus yang menjadikannya sebagai siklus abadi. Tanpa siklus ini tidak akan terjadi kehidupan. Keterkaitannya dengan amerta sebagai air kehidupan di laut, laut dikuasai oleh Dewa Baruna yang digambarkan sebagai penyatuan wujud raja naga-gajah besar-dengan bermulutkan ikan (makara) sebagai penguasa laut, yang menjaga laut (Paramadhyaksa, 2011).

Pada lingkaran siklus air, Dewa Wisnu sebagai dewa air mengijinkan Dewi Gangga turun ke dunia atas permohonan Maharaja Bhagiratha untuk menyucikan arwah leluhurnya yang dikutuk oleh Maharsi Kapila. Gangga minta kepada Bhagirata untuk memohon perkenan Dewa Siwa untuk membendung curahan Dewi Gangga yang turun dari surga ke bumi, karena khawatir bumi akan hancur dan terjerembab ke Patala akibat derasnya aliran sungai suci itu. Untuk menghindarkan hal itu, Dewa Siwa berkenan memenuhi permohonan Bhagiratha, untuk membendung Sungai Gangga dengan gelung rambutnya yang dijalin sedemikian rupa (Titib, 2009: 258). Siwa sebagai Parwata Raja Dewa secara simbolis merupakan perwujudan alam semesta dengan gunung sebagai pusat dan hulu, rambut sebagai tumbuhan dan segala yang tumbuh di dunia, sebagai penahan air, menyimpan air lalu memunculkan mata air yang murni, penuh kandungan mineral dari zat alam yang sangat bermanfaat bagi setiap mahluk.

\section{Air Sebagai Makna Pelestarian}

Penyelamatan sumber air di Bali, yang berpotensi mengalirkan air ke sungai utama, dan aliran ini dapat merupakan aliran air bawah tanah (ground water) dan air permukaan (surface water) yang bermuara ke laut. Pada sumber mata air dalam tanah dan air serapan yang keluar dari celah-celah tebing. Air merupakan salah satu sumber daya alam yang mempunyai peranan penting dalam kehidupan manusia, yaitu mempunyai potensi membersihkan menyucikan dan sebagai sumber kehidupan. Tanpa adanya upaya pengelolaan air dengan baik akan berakibat bencana, seperti

\section{VIDYA WERTTA}

Vol. 1 Nomor 2, Oktober 2018 
pada musim hujan sering terjadi bencana alam, tanah longsor, dan banjir bandang. Kenyataan ini merupakan akibat dari kecerobohan manusia mengeksploitasi alam tanpa mengindahkan dampak yang ditimbulkan (Bagus, 2008: 62- 63).

Masyarakat Bali Kuna menyelamatkan sumber air dengan lingkungannya dengan kearifan lokal yang mereka miliki, dengan membuat kolam suci dan airnya dipergunakan tirtha (air suci) yang dipergunakan dalam upacara panca yadnya. Dengan cara ini masyarakat tidak akan berani merusak lingkungan yang ada dan akan dikenakan sanksi adat. Fungsi tebing berperan dalam proses infiltrasi, air permukaan yang masuk ke daerah tebing akan terjadi proses penyaringan air dari partikel (sedimen, bakteri atau unsur organisme lainnya) sehingga air tersebut menjadi jernih bahkan di beberapa tempat bisa langsung dikonsumsi dengan aman, tanpa memerlukan perlakuan lebih lanjut (Geria, 2012: 11-13).

Jadi pembuatan petirthaan, candi, candi tebing, ceruk pertapaan pada dasarnya mempunyai makna pelestarian sumber air, agar kawasan tersebut disucikan dan terlindungi dari eksploitasi. Masyarakat Bali Kuna benar-benar memposisikan sungai dengan airnya yang mengalir sebagai ratna permata bumi yang bernilai luhur. Di jaman globalisasi ini keberpihakan manusia terhadap daerah aliran sungai sangat memprihatinkan, sungai dengan airnya yang mengalir diposisikan amat nista yaitu sebagai tempat pembuangan sampah dan berbagai kotoran, bahkan limbah industri yang beracun.

Sejumlah kawasan DAS yang ada di daerah kawasan pariwisata mengandung fibrasi kesucian sering dilanggar untuk kepentingan bisnis. Tebing-tebing dan sempadan sungai banyak ditumbuhi bangunan megah, semuanya itu hanya untuk kepentingan pariwisata tanpa memperhatikan kelangsungan sungai ke depan. Bangunan-bangunan yang didirikan di kawasan tebing dan sempadan sungai merupakan tindakan perusakan lingkungan, akibalnya resapan air menjadi berkurang sehingga tidak bisa dihindari banjir akan mengancam keberadaan penduduk di kawasan hilir. Untuk menanggulangi perilaku kontra produktif terhadap lingkungan pemerintah harus berangkat dari strategi budaya dengan mengedepankan spirit fibrasi kesucian alam dengan berpedoman pada caracara leluhur masyarakat Bali Kuno. Menyucikan Daerah Aliran sungai, mempunyai makna pelestarian sumber budaya air dan untuk menjaga kesinambungan hidrologi. Manusia selalu menjaga hubungan adaptasi dengan lingkungan berdasarkan budaya yang dimiliki berupa gagasan yang membentuk tingkah laku seseorang atau kelompok dalam ekosistem. Memelihara kesucian lingkungan sungai dengan tujuan agar masyarakat tidak mengeksploitasi, karena ada nilai spiritual dan religius yang merupakan unsur yang kuat dalam menjaga keasrian lingkungan. Pembuatan kolam pada bangunan suci fungsinya untuk kepentingan religius juga mempunyai makna pengelolaan air, karena kolam fungsinya sebagai tempat serapan buatan, menampung luapan air dari sumber mata air yang debitnya tinggi, sehingga air tanah kelangsungan proses hidrologi. Tanaman vegetasi yang besar dilindungi dan disucikan, tempat curam sungai disakralkan, merupakan kearifan hidrologi masa lalu yang cukup bijak bila dikembangkan sekarang mengingat

\section{VIDYA WERTTA}

Vol. 1 Nomor 2, Oktober 2018 
kawasan tebing serta tumbuh-tumbuhan vegetasi yang besar terlindung, dan merupakan daerah tangkapan air.

\section{PENUTUP}

Berdasarkan hasil kajian yang telah dilakukan, maka dapat ditarik kesimpulan sebagai berikut: pemanfaatan air di masyarakat bersumber dari ajaran Veda, yang memiliki makna di masing - masing pemanfaatan tersebut. Adapun pemanfaatan dan makna air dalam Veda sebagai berikut: air sebagai makna penyembuhan, makna kesuburan, makna penyucian, makna keabadian, makna siklus, dan air sebagai makna pelestarian.

\section{SARAN}

Adapun saran yang dapat disampaiakan sehubungan penulisan ini sebagai berikut: diharapkan penelitian ini dapat dijadikan sebagai pedoman atau perbandingan penelitian selanjutnya mengenai pemanfaatan dan makna air dalam Veda.

\section{DAFTAR PUSTAKA}

Ardika, I Wayan, 2003. Laut dan Orientasi dalam Kebudyaan Bali: Dalam I Gde Semadi Astra (Ed). Guratan Budaya dalam Perspektif Multikultural: 90 - 99. Denpasar: Fakultas Satra dan Budaya, Universitas Udayana.

Bagus, A.A. Gde. 2008. Pelestarian Daerah Aliran Sungai Pakerisan. Perspektif Lingkungan. dalam Forum Arkeologi. (3): 63 - 91.
Budi Adnyana, G.A, 2009. Air Menurut Veda. Cetakan I. ISSN: 978979-8496-92-9. Pustaka Bali Post. Denpasar Bali.

Geria, I Made. 2012. Penguatan Jatidiri dalam Perspektif Aktualisasi Arkeologi. Dalam Made Sutaba (Ed). Merajut Kearifan Lokal Membangun Karakter Bangsa: 1 -20. Denpasar: Kementrian Pariwisata dan Ekonomi Kreatif dan Balai Arkeologi Denpasar.

Jendra, I Wayan. 2008. Tuhan Sudah Mati? Untuk Apa Sembahyang (Sebuah Studi Religiofilosofis Brahmawidya). Surabaya: Paramita.

Panitia Penyusun. 1997. Adi Parwwa. Denpasar: Dinas Pendidikan Dasar, Propinsi Daerah Tingkat I Bali.

Paramadhyaksa, I Nyoman Widya. 2011. Makna- Makna Figur Naga dalam Budaya Tradisional Bali. Forum Arkeologi. (3): 263279.

Sedyawati, Edi. 2009. Semiotika dalam Arkeologi: Candi Jago dalam Tinjauan Semiotik. Dalam Edi Sedyawati (Ed). Saiwa dan Bauddha di Masa Jawa Kuno. Denpasar: Widya Darma.

Susanto, Nugroho. 1999. Simbolisme dalam Arkeologi. Dalam Dewan Redaksi. Kumpulan Makalah Pertemuan Ilmiah Arkeologi. (8): 496 - 498. Yogyakarta: IAAI Indonesia.

Utami, Luh Suwita dan I Putu Yuda Haribuana. 2013. Penelitian Peradaban dalam Pengelolaan Sumber Air (Hidro-Arkeologi) 
di Kawasan Penebel Tabanan Bali. Laporan Penelitian, Balai Arkeologi Denpasar.

Tim Bali Post. 2010. Ajeg Bali, Sebuah Cita-Cita. Denpasar: Bali Post .

Tim Penyusun. 2007. Kamus Bahasa Bali, Bali- Indonesia. Surabaya: Paramita.

Tim Penyusun. 2013. Sejarah Bali. Denpasar: Udayana University Press.

Titib, I Made. 2009. Teologi dan Simbol-Simbol dalam Agama Hindu. Surabaya: Paramita.
Triguna, Ida Bagus Gde Yudha. 2000. Teori Tentang Simbol. Denpasar: Widya Dharma, Universitas Hindu Indonesia.

Wiana, I Ketut. 2005. Ajeg Bali Adalah Tegaknya Kebudayaan Hindu di Bali. Dalam Made Titib (Ed). Dialog Ajeg Bali: 141 - 184 . Surabaya: Paramita.

Windia, Wayan. 2006. Transformasi Sistem Irigasi Subak, yang Berlandaskan Konsep Tri Hita Karana. Denpasar: Pustaka Bali Post. 